\title{
Filmography
}

\section{As designer}

The Devils, 1971, dir. Ken Russell

Savage Messiah, 1972, dir. Ken Russell

\section{As director}

Some of the problems in arriving at an accurate list of the short films are discussed in Chapter 2. The following is based on the work of Michael O'Pray, James Mackay, and Tony Peake, and is a simplified and slightly amended version of the list given in Tony Peake's biography of Derek Jarman. Some of the dates are not certain, but one thing which is fairly certain (despite a good deal of published information to the contrary including statements by Jarman himself) is that none of Jarman's super-8 films, beginning with Studio Bankside, can be earlier than the summer of 1972 , which is when he was first shown a super-8 camera by Marc Balet.

\section{Short films}

Electric Fairy, 1971, 16mm

Studio Bankside, 1972, super-8, col. and b/w

The Siren and the Sailor, 1972 (aka At Low Tide), super-8, col.

Miss Gaby, 1972 (aka Miss Gaby Gets it Together or All our Yesterdays), super-8, col.

Andrew Logan Kisses the Glitterati, 1973, super-8, col.

Andrew, 1973, super-8, col.

Red Movie, 1973 (aka Tourist Film), super-8, col. shot through red filter 
Stolen Apples for Karen Blixen, 1973, super-8, b/w

Gerald Plants a Flower, 1973, super-8

Gerald Takes a Photo, 1973, super-8

Tarot, 1973 (aka The Magician), super-8, col.

A Garden in Luxor, 1973 (aka Garden of Luxor), super-8, col.

Kevin Whitney, 1973, super-8, col.

The Art of Mirrors, 1973, super-8, col.

Beyond the Valley of the Garden of Luxor Revisited, 1973, super-8, col.

Burning of Pyramids, 1973, super-8, col.

Death Dance, 1973, super-8, col.

Arabia, 1973, super-8, col. and b/w

Green Glass Bead Game, 1973, super-8, col.

Sulphur, 1973, super-8, col.

Journey to Avebury, 1973, super-8, col.

Ashden's Walk on Mon, 1973 (aka Walk on Mon or Space Travel, A Walk on Mon), super-8, col.

Shad Thames, 1973, super-8, b/w

Cafe in Tooley Street, 1973, super-8

Miss World, 1973, super-8, b/w and shot through pink filter

Fred Ashton Fashion Show, 1974, super-8, col.

Bill Gibb Show, 1974, super-8, col.

Duggie Fields at Home, 1974 (aka Duggie Fields), super-8, col.

Picnic at Rae's, 1974 (aka Lunch at Rae's), super-8, col.

Herbert in NYC, 1974 (aka New York Walk Don't Walk), super-8, col.

New York City, 1974 (aka NYC), super-8, col.

Dinner and Diner, 1974, super-8, b/w

The Devils at the Elgin, 1974 (aka Reworking the Devils or Sister Jean of the Angels), super-8, b/w

Fire Island, 1974, super-8, col.

My Very Beautiful Movie, 1974, super-8, col.

The Kingdom of Outremer, 1974, super-8, col.

In the Shadow of the Sun, 1974-1980, 50 min., super-8 blown up to $16 \mathrm{~mm}$ in 1980, col.

Production company: Dark Pictures

Producer: James Mackay

Music: Throbbing Gristle 
Sloane Square, 1974-76 (aka Removal Party), super-8, col.

Corfe Film, 1975 (aka Troubadour Film), super-8, col.

Ken Hicks, 1975, super-8, col.

Sebastiane Wrap, 1975 (aka Sebastiane Mirror Film or Mirrors or A Break from Sebastiane), super-8 blown up to $16 \mathrm{~mm}$ in 1981, col.

Karl at Home, 1975, super-8, b/w

Gerald's Film, 1975, super-8, col.

The Sex Pistols in Concert, 1976, super-8, b/w, included in The Great Rock 'n' Roll Swindle, dir. Julien Temple (1980)

Ulla's Fete, 1976 (aka Ulla's Chandelier), super-8, b/w

Houston Texas, 1976, super-8, col.

The Sea of Storms, 1976 (aka Kingdom), super-8, b/w

Jordan's Dance, 1977, super-8, col., sections of this included in Jubilee

Jubilee Masks, 1977 (aka Jean-Marc Makes a Mask), super-8, b/w

Art and the Pose, 1977 (aka Arty the Pose), super-8, b/w, later blown up to $16 \mathrm{~mm}$ and included in The Dream Machine (1984)

Every Woman for Herself and All for Art, 1978, super-8 blown up to $16 \mathrm{~mm}$ in $1981, \mathrm{~b} / \mathrm{w}$

The Fountain, 1978, super-8, col.

The Pantheon, 1978, super-8, col.

Italian Street Scene, 1978, super-8, col.

Italian Ruins, 1978, super-8, col.

Broken English: Three Songs by Marianne Faithfull, 1979, 12 min., super-8 and $16 \mathrm{~mm}$ blown up to $35 \mathrm{~mm}$, col. and b/w, includes 'Witches Song', 'The Ballad of Lucy Jordan', and 'Broken English'

TG Psychic Rally in Heaven, 1981, 8 min., super-8 blown up to $16 \mathrm{~mm}$, col.

Jordan's Wedding, 1981, super-8, col.

Rakes Progress, 1982, super-8, col.

Pontormo and Punks at Santa Croce, 1982, super-8, col.

B2 Movie, 1982, super-8 transferred to video, col. and b/w

Waiting for Waiting for Godot, 1982, super-8 and video, col. and b/w

Pirate Tape, 1982, super-8 later transferred to $16 \mathrm{~mm}$ and video

Diese Machine ist Mein Antihumanistiches Kunstwerk, 1982, super-8, b/w

Touch the Radio, Dance!, 1983, promotional video for Steve Hale, col.

Dance with Me, 1983, promotional video for Lords of the New Church, col. 
Home Movie Dong, 1983 (aka The Dong with the Luminous Nose), super-8 fragment

Willow Weep for Me, 1983, promotional video for Carmel, $16 \mathrm{~mm}$, col.

Dance Hall Days, 1983, promotional video for Wang Chung, col.

Working for Pleasure, 1984, super-8, b/w

Wide Boy Awake, 1984, promotional video for Billy Hyena, 16mm, col.

Catalan, 1984, promotional video for Jordi Vallis, $16 \mathrm{~mm}$, col.

Barcelona, 1984, super-8, col. and b/w

What Presence, 1984, promotional video for Orange Juice, $16 \mathrm{~mm}$, col.

Oxford Medley Show, 1984, super-8, col.

Imagining October, 1984, 27 min., super-8 and video blown up to $16 \mathrm{~mm}$, col. and $b / w$

Producer: James Mackay

Executive producer: Francesca Forbes Moffat

Text: Shaun Allen and Derek Jarman

Editing: Cerith Wyn Evans, Richard Heslop, Derek Jarman, and Peter Cartwright

Artwork: Christopher Hobbs

Music: Genesis P-Orridge and David Ball

Tenderness is a Weakness, 1984, promotional video for Marc Almond, $16 \mathrm{~mm}$, col.

Windswept, 1985, promotional video for Bryan Ferry, 16mm, col.

Short film for 'Action Against Aids' gala performance of Walter Reynolds's Young England at the Adelphi Theatre, I8 June I986, super-8

Untitled promotional film for Matt Fretton, I986, super-8

The Queen is Dead: Three Songs by the Smiths, 1986, super-8 edited onto video and blown up to $35 \mathrm{~mm}$, col. and b/w, includes 'The Queen is Dead', 'There is a Light that Never Goes Out', and 'Panic'

Ask, 1986, promotional video for the Smiths, super-8, col.

Whistling in the Dark, 1986, promotional video for Easterhouse, super8 , col. and b/w

1969, 1986, promotional video for Easterhouse, super-8, col. and b/w

Depuis le Jour, 1987, sequence in portmanteau film Aria, super-8 and $35 \mathrm{~mm}$, col. and b/w

Producer: Don Boyd

Sequence producer: James Mackay

Photography: Chris Hughes (super-8) and Mike Southon (35mm)

Editing: Peter Cartwright and Angus Cook 
Production design: Christophe Hobbs

Music: Gustave Charpentier from his opera Louise

Costumes: Sandy Powell

Leading players: Aimée Delamaine (incorrectly credited as Amy Johnson), Tilda Swinton, Spencer Leigh

Out of Hand, 1987, promotional video for the Mighty Lemon Drops, super- 8 and $16 \mathrm{~mm}$, col.

I Cry Too, 1987, promotional video for Bob Geldof, super-8 and 8mm video, col.

In the Pouring Rain, 1987, promotional video for Bob Geldof, super-8 and $8 \mathrm{~mm}$ video, col.

It's a Sin, 1987, promotional video for the Pet Shop Boys, 35mm, col.

Rent, 1987, promotional video for the Pet Shop Boys, $35 \mathrm{~mm}$ and super8 , col. and b/w

L'ispirazione, 1988, super-8 edited on video and blown up to $35 \mathrm{~mm}$, col.

Backdrops for Pet Shop Boys Concert, 1989, eight short films made as backdrop projections for the 1989 Pet Shop Boys Tour, super-8 and $16 \mathrm{~mm}$ blown up to $70 \mathrm{~mm}$, col. and b/w, includes 'Opportunities', 'Heart', 'Paninaro', ‘Nothing Has Been Proved', 'It's a Sin', ‘Domino Dancing', 'King's Cross', and 'Always on my Mind'

Highlights: Pet Shop Boys on Tour, 1990, film of the Pet Shop Boys in concert at Wembley in July 1989 and including the eight films made as backdrops, super- 8 and $16 \mathrm{~mm}$ transferred to video, col. and b/w

Red Hot and Blue, 1990, video of Cole Porter songs sung by different artists, includes extracts from Jarman's home movies to accompany Annie Lennox singing 'Every Time We Say Goodbye'

Little Emerald Bird, 1993, promotional video for Patti Smith, super-8, col.

Projections, 1993, release on video of seven of the eight films made as backdrops for the Pet Shop Boys (the missing one is 'Nothing Has Been Proven'), together with two further songs, 'Violence' (to an excerpt from Garden in Luxor) and 'Being Boring' (to an excerpt from Studio Bankside), col. and b/w

Glitterbug, 1994, 60 min., montage of super-8 footage shot by Jarman between 1971 and 1988, super-8 blown up to $35 \mathrm{~mm}$, col. and b/w

Production company: Basilisk Communications and BBC

Producer: James Mackay

Associate director: David Lewis

Editing: Andy Crabb

Music: Brian Eno 


\section{Feature films}

Sebastiane, 1976, $86 \mathrm{~min}$., $16 \mathrm{~mm}$ blown up to $35 \mathrm{~mm}$, col.

Co-director: Paul Humfress

Production company: Distac

Producers: James Whaley and Howard Malin

Screenplay: Derek Jarman and James Whaley

Photography: Peter Middleton

Editing: Paul Humfress

Music: Brian Eno

Sound: John Hayes

Leading players: Leonardo Treviglio (Sebastian), Barney James (Severus), Neil Kennedy (Max), Richard Warwick (Justin), Ken Hicks (Adrian), Donald Dunham (Claudius), Janusz Romanov (Anthony), Steffano Masari (Marius), Daevid Finbar (Julian), Gerald Incandela (Leopard Boy), Robert Medley (Diocletian)

Jubilee, 1978, $104 \mathrm{~min} ., 16 \mathrm{~mm}$ and super-8 blown up to $35 \mathrm{~mm}$, col.

Production company: Whaley-Malin Productions for Megalovision

Producers: Howard Malin and James Whaley

Screenplay: Derek Jarman and James Whaley

Photography: Peter Middleton

Editing: Nick Barnard

Music: Brian Eno

Sound: John Hayes

Costumes and design: Christopher Hobbs

Leading players: Jenny Runacre (Bod/Queen Elizabeth I), Little Nell (Crabs), Toyah Willcox (Mad), Jordan (Amyl Nitrate), Hermine Demoriane (Chaos), Ian Charleson (Angel), Karl Johnson (Sphinx), Linda Spurrier (Viv), Neil Kennedy (Max), Orlando/Jack Birkett (Borgia Ginz), Wayne County (Lounge Lizard), Richard O’Brien (John Dee), David Haughton (Ariel), Helen Wallington-Lloyd (Lady-in-Waiting), Adam Ant (Kid), Donald Dunham and Barney James (Policemen), Ulla Larson-Styles (Waitress), Howard Malin (Schmeitzer)

The Tempest, 1979, 95 min., $16 \mathrm{~mm}$ blown up to $35 \mathrm{~mm}$, col.

Production company: Boyd's Company

Producers: Guy Ford and Mordecai Schreiber

Associate producer: Sarah Radclyffe

Executive producer: Don Boyd

Screenplay: Derek Jarman, based on the play by William Shakespeare

Photography: Peter Middleton

Editing: Lesley Walker 
Art direction: Ian Whittaker

Music and electronic sound: Wavemaker

Sound: John Hayes

Costumes and design: Yolanda Sonnabend

Leading players: Heathcote Williams (Prospero), Karl Johnson (Ariel), Toyah Willcox (Miranda), Peter Bull (Alonso), Richard Warwick (Antonio), Elisabeth Welch (Goddess), Jack Birkett (Caliban), Ken Campbell (Gonzalo), David Meyer (Ferdinand), Neil Cunningham (Sebastian), Christopher Biggins (Stephano), Peter Turner (Trinculo), Claire Davenport (Sycorax), Helen Wallington-Lloyd and Angela Whittingham (Spirits), Kate Temple (Young Miranda)

The Angelic Conversation, 1985, 78 min., super-8 edited on to video and blown up to $35 \mathrm{~mm}$, col. and b/w

Production company: British Film Institute and Channel Four

Producer: James Mackay

Screenplay: Fourteen Shakespeare sonnets (read by Judi Dench)

Photography: Derek Jarman and James Mackay

Editing: Cerith Wyn Evans and Peter Cartwright

Music: Coil

Sound editing: Richard Anstead and Peter Christopherson

Leading players: Paul Reynolds, Philip Williamson, Dave Baby

Caravaggio, 1986, $93 \mathrm{~min} ., 35 \mathrm{~mm}$, col.

Production company: British Film Institute in association with Channel Four and Nicholas Ward-Jackson

Producer: Sarah Radcliffe

Executive producer: Colin MacCabe

Screenplay: Derek Jarman from an original idea by Nicholas Ward-Jackson Photography: Gabriel Beristain

Editing: George Akers

Design: Christopher Hobbs

Art Direction: Mike Buchanan

Music: Simon Fisher Turner

Sound: Billy McCarthy

Costumes: Sandy Powell

Leading players: Nigel Terry (Caravaggio), Sean Bean (Ranuccio), Tilda Swinton (Lena), Spencer Leigh (Jerusaleme), Gary Cooper (Davide), Dexter Fletcher (Young Caravaggio), Nigel Davenport (Giustiniani), Robbie Coltrane (Scipione Borghese), Michael Gough (Cardinal del Monte), Noam Almaz (Boy Caravaggio), Dawn Archibald (Pipo), Jack Birkett (Pope), Jonathan Hyde (Baglione), Emil Nicolaou (Young Jerusaleme), Zohra Segal (Jerusaleme's grandmother) 


\section{FILMOGRAPHY}

The Last of England, 1987, 87 min., super-8 and video blown up to $35 \mathrm{~mm}$, col. and b/w

Production company: Anglo International Films for British Screen, Channel Four, and ZDF

Producers: James Mackay and Don Boyd

Associate producers: Yvonne Little and Mayo Thompson

Photography: Derek Jarman, Christopher Hughes, Cerith Wyn Evans, and Richard Heslop

Editing: Peter Cartwright, Angus Cook, John Maybury, and Sally Yeadon

Production design: Christopher Hobbs

Sound design: Simon Turner

Sound: Matthew Evans and Chris Gurney

Sound editing: Budge Tremlett

Voice-over: Nigel Terry

Costumes: Sandy Powell

Leading players: Tilda Swinton, Spencer Leigh, Spring, Matthew Hawkins, Gerrard McArthur, James Mackay, Adam Elliott

War Requiem, 1989, 93 min., super-8 and 35mm, col. and b/w

Production company: Anglo International Films

Producer: Don Boyd

Associate producer: Chris Harrison

Executive producer: John Kelleher

Screenplay: Derek Jarman

Photography: Richard Greatrex

Editing: Rick Elgood

Video editing: John Maybury

Design: Lucy Morahan

Sound: Garth Marshall

Original recording of Britten's War Requiem: Dietrich Fischer-Dieskau (baritone), Peter Pears (tenor), Galina Vishnevskaya (soprano)

Costumes: Linda Alderson

Leading players: Nathaniel Parker (Wilfred Owen), Tilda Swinton (Nurse), Owen Teale (Unknown Soldier), Sean Bean (Enemy Soldier), Patricia Hayes (Mother), Rohan McCullough (Enemy Mother), Nigel Terry (Abraham), Claire Davenport (Charge Sister/Britannia)

The Garden, 1990, 92 min., super-8, video, and 16mm blown up to $35 \mathrm{~mm}$, col.

Production company: Basilisk in association with Channel Four, British Screen, ZDF, and Uplink

Producer: James Mackay 
Photography: Christopher Hughes

Editing: Peter Cartwright

Music: Simon Fisher Turner

Sound: Gary Desmond

Sound editing: Nigel Holland

Voice-over: Michael Gough

Costumes: Annie Symons

Leading players: Tilda Swinton (Madonna), Johnny Mills and Kevin Collins (Lovers), Peter Lee-Wilson (Devil), Spencer Leigh (Mary Magdalen), Jody Graber (Young Boy), Roger Cook (Christ), Philip Macdonald (Judas)

Edward II, 1991, $90 \mathrm{~min} ., 35 \mathrm{~mm}$, col.

Production company: Working Title in association with British Screen and BBC Films

Producers: Steve Clark-Hall and Antony Root

Executive producers: Sarah Radclyffe, Simon Curtis, and Takashi Asai

Associate director: Ken Butler

Screenplay: Derek Jarman, Stephen McBride, and Ken Butler, based on the play by Christopher Marlowe

Photography: Ian Wilson

Editing: George Akers

Production design: Christopher Hobbs

Art direction: Rick Eyres

Music: Simon Fisher Turner

Sound: George Richards

Costumes: Sandy Powell

Leading Players: Steven Waddington (Edward II), Andrew Tiernan (Gaveston), Tilda Swinton (Isabella), Nigel Terry (Mortimer), Kevin Collins (Lightborn), John Lynch (Spencer), Jody Graber (Prince Edward), Jerome Flint (Kent), Dudley Sutton (Bishop of Winchester)

Wittgenstein, 1993, $75 \mathrm{~min} ., 35 \mathrm{~mm}$, col.

Production company: Bandung for Channel Four, the British Film Institute, and Uplink

Producer: Tariq Ali

Executive producers: Ben Gibson and Takashi Asai

Executive in charge of production: Eliza Mellor

Associate director: Ken Butler

Screenplay: Derek Jarman, Terry Eagleton, and Ken Butler

Photography: James Welland

Editing: Budge Tremlett

Art direction: Annie Lapaz

Music: Jan Latham-Koenig 


\section{FILMOGRAPHY}

Sound: George Richards

Sound editing: Toby Calder

Costumes: Sandy Powell

Leading Players: Karl Johnson (Ludwig Wittgenstein), Michael Gough (Bertrand Russell), Tilda Swinton (Ottoline Morrell), John Quentin (Maynard Keynes), Kevin Collins (Johnny), Clancy Chassay (Young Ludwig Wittgenstein), Nabil Shaban (Martian), Jill Balcon (Leopoldine Wittgenstein)

Blue, 1993, $79 \mathrm{~min} ., 35 \mathrm{~mm}$, col.

Production company: Basilisk Communications and Uplink in association with Channel Four

Producers: James Mackay and Takashi Asai

Associate director: David Lewis

Screenplay: Derek Jarman

Music: Simon Fisher Turner

Sound design: Marvin Black

Voice-overs: Nigel Terry, John Quentin, Tilda Swinton, and Derek Jarman 